\title{
ПРОБЛЕМЫ ПОСТРОЕНИЯ СИСТЕМЫ АДАПТАЦИИ КАК ФАКТОР РАЗВИТИЯ КАДРОВОГО ПОТЕНЦИАЛА: ОПЫТ РОССИЙСКОГО ПРЕДПРИЯТИЯ (НА ПРИМЕРЕ ОАО ПКК «ВЕСНА»)
}

\author{
(c) 2019 Коновалова Анастасия Игоревна \\ студент \\ (C) 2019 Сумина Надежда Навловна \\ студент \\ E-mail:kon63nas@yandex.ru

\section{(c) 2019 Полынова Людмила Викторовна \\ кандидат экономических наук, доцент}

В статье описывается опыт построения системы адаптации персонала на одном из российских предприятий - OAO «Весна». В частности, рассматриваются результаты аудита действующей системы адаптации на ОАО «Весна». По итогам исследования были выявлены слабые стороны и предложены основные этапы построения скорректированной системы адаптации.

Ключевые слова: адаптация персонала, системы адаптации персонала, наставничество, этапы построения системы адаптации.

Основой, на которой строится любая современная организация, без сомнений, является качественно подготовленный персонал, так как именно профессиональные сотрудники обеспечивают эффективность работы организации.

Помочь сотруднику успешно влиться в новую организацию, адаптироваться и остаться в ней - важная задача руководителя и специалиста по управлению персоналом. Адаптация личности в коллективе обусловливает устойчивость и стабильность этого коллектива, повышает его сплоченность, что способствует улучшению морально-психологического климата, нормальному функционированию и развитию коллектива, а, следовательно, эффективности организации. Процесс адаптации является главным этапом для профессионального становления работников. Адаптация способствует установлению контактов на рабочем месте, что в дальнейшем ведет к более продуктивному взаимодействию, что непосредственно сказывается на результате труда.

На большинстве российских предприятий остро стоит проблема адаптации персонала. Значительно количество увольнений, как правило, происходит в начальный период. В этот период человеку необходимо влиться в коллектив, чтобы почувствовать себя комфортно на новом месте. Также, естественно, необходимо сохранить уже имеющихся работников. То есть для поддержания кадрового потенциала необходимо сохранить опытных работников и привлечь новые силы.

Указанная проблема действительно актуальна на сегодняшний день, так как кадровые службы порой не относятся серьезно к этой проблеме и даже не разрабатывают адаптационные программы. Каждый принятый сотрудник нуждается в индивидуальном подходе, который должен осуществляться руководством. Данная проблема существует и в ОАО ПКК «Весна».

Компания «Весна» сегодня - это современное динамично развивающееся предприятие, которое входит в число крупнейших российских производителей средств по уходу за кожей, гигиены полости рта и товаров бытовой химии. На собственном производстве, полностью оснащенным современным западным оборудованием, выпускается свыше 300 ассортиментных видов продукции. Область деятельности компании производство бытовой химии и средств по уходу за кожей лица, тела и волосами. Занимается производством моющих средств, стиральных порошков, мыла, зубных паст.

Однако результаты хозяйственной деятельности предприятия заставили обратить внимание руководства на динамику некоторых показателей, в частности численности работников и текучести персонала. Так, за период 2015-2018 года уровень текучести повысился на 5\%. Для 
выявления причин создавшиеся ситуации на предприятии было проведено исследование.

В ходе анкетирования сотрудников были найдены как позитивные, так и негативные стороны. К положительным моментам можно отнести следующее:

1) На ОАО «Весна» проводятся общие мероприятия, способствующие адаптации нового сотрудника: собеседование с руководителем подразделения, в которое устраивается человек, оформление нового сотрудника, разъяснения по системе оплаты труда и графика работы, инструктаж по охране труда у инспектора по ОТ и ТБ, инструктаж непосредственного руководителя на рабочем месте, экскурсия по отделам с кратким представлением новичка сотрудникам (фамилия, имя, отчество, должность). Работника дополнительно знакомят с Правилами внутреннего трудового распорядка, Положением о материальном стимулировании труда и другими локальными нормативными документами (у 90\% опрошенных).

2) Непосредственный руководитель нового сотрудника знакомит его с персоналом подразделения и рабочим местом, с процедурами, правилами, инструкциями, предписаниями, основными целями и задачами подразделения (у 100\% опрошенных).

3) Результаты работы обсуждаются с руководителем еженедельно (у 85\% опрошенных).

4) В случае возникновения вопросов сотрудники могут сразу же обратиться за объяснением к своему наставнику (у 90\% опрошенных).

Были выявлены следующие недостатки:

1) На предприятии в принципе отсутствует детально проработанная программа адаптации новых сотрудников (у 100\% опрошенных).

2) Отсутствует документально оформленная системы наставничества для всех подразделений и отделов (у 100\% опрошенных).

3) Не поощряется работа наставника ни материально, ни морально. Оплата за труд наставника незначительна, работа не позиционируется как привилегия, в результате этого сотрудники выполняют обязанность наставника с неохотой, что негативно сказывается на усвоении навыков и знаний нового сотрудника (у 85\% опрошенных).

4) Не проработана технология наставничества, а именно:

а) отсутствует процедура действий наставника на период вхождения в должность нового сотрудника (у 100\% опрошенных).

б) не прописаны критерии оценки деятельности новичка и система вознаграждения для наставника и его подопечного не всегда рабочее место укомплектовано к моменту прибытия нового сотрудника на работу (у 90\% опрошенных).

5) Одним из основных недостатков адаптационных мероприятий в ОАО «Весна» является то, что перед новыми сотрудниками не ставятся конкретные задачи на испытательный срок. Следовательно, во время и по истечении испытательного срока не оценивается его уровень подготовки, знаний и навыков. Таким образом, контроль выполнения задач новым сотрудником отсутствует.

Результаты успешной или напротив неудачной адаптации к новому коллективу и новому рабочему месту сказываются не только на самочувствии работника, но и на эффективности его работы, а, значит, и на всем предприятии в целом.

Во время прохождения адаптационного периода новым сотрудником предприятию очень важно постоянно оценивать и поддерживать высокий уровень удовлетворенности. Высокая удовлетворенность персонала позволяет организации не только снизить текучесть кадров, но также противостоять проблеме дефицита трудовых ресурсов, которая на сегодняшний день особенно остро проявляется в отношении высококвалифицированных специалистов, обеспечивающих ключевые направления деятельности организации.

Все вышеперечисленное объясняет необходимость корректировки системы адаптации, её дальнейшее совершенствование. Были определены следующие основные действия развития системы адаптации (этапы построения):

1. Закрепить функцию по адаптации за сотрудником из управления персоналом и техническим обучением.

2. Разработать и внедрить следующие локальные нормативные акты, регулирующие процесс адаптации:

- Положение об адаптации нового сотрудника;

- Положение о наставничестве.

3. Разработать критерии оценки деятельности новичка.

4. Разработать систему вознаграждения наставника, как материальную (например, премии, надбавки), так и моральную (грамоты, бла- 
годарности).

5. Разработать программу вовлечения новичков в трудовую жизнь предприятия, путём организации совместных массовых мероприятий (выезды на природу, проведение творческих конкурсов для работников и их детей).

6. Повысить уровень информированности всех сотрудников предприятия о делах фирмы, путем организации соответствующих публикаций в корпоративном издании (газете) и на сайте.

\section{Библиографический список}

1. Климашин, И.А. Адаптация: методика, технология, опыт /И.А.Климашин// статья HR-Portal.-2015, стр. 5055

2. Шведова, Т.О. Организация системы адаптации новых сотрудников. / Т. О. Шведова / / Управление персоналом:100\% практика, Москва - 2014 г. - № 5, стр. 2-6.

3. Шейн Э.Г. Организационная культура и лидерство. 3-е изд., 2011 год, издательство «Питер», 336 стр.

4. Канавина Н.И., Полынова Л.В. «Адаптация персонала как фактор поддержания кадрового потенциала: опыт российского предприятия» // «Вопросы экономики и права, научно-информационный журнал»/ 2015, № 9, стр. 114-116

5. Кирилина Ю.Н., Полынова Л.В. «Проблемы совершенствования системы адаптации персонала: опыт российского производственного предприятия», журнал «Экономика и предпринимательство», № 10, ч.1, 2016, стр. $536-538$
Разработанные рекомендации уже показали свою практическую значимость для ОАО «Весна», так как: во-первых, руководство осознало важность проблемы адаптации персонала; во-вторых, проведенный аудит системы адаптации помог систематизировать слабые места и

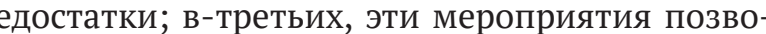
сотрудников, а в конечном счете и организации в целом. 